\title{
INVESTMENT FUNDS WITH LEGAL PERSONALITY - A TRUE RIVAL TO MUTUAL FUNDS?*
}

\author{
Morana Derenčinović Ruk ** \\ Mihaela Braut Filipović c*** $^{* *}$ \\ Suzana Audić Vuletić
}

\begin{abstract}
Investment funds come in a large variety of legal forms, investment techniques, target investors, redemption rights, and others. It is often said that there are no two investment funds that are the same. The focus of this article is the legal form in which they come. Authors shall analyze the position of investors in funds with legal personality in order to discuss differences in comparison to investors in mutual funds. On the EU level only the UCITS funds are harmonized, while alternative investment funds are left to national regulations. The aim is to discuss whether the legal status of investment funds is a real yardstick for determining the crucial investor's rights such as redemption rights and relations between the investors and fund managers. In order to provide answer authors shall compare funds in jurisdictions that are comparable and often serve as role models, as well as those in which the fund industry is most developed, followed by the Croatian perspective. Finally, the authors shall contribute to the discussion of how can traditional types of companies such as joint-stock or
\end{abstract}

This paper is written under support of the University of Rijeka project (uniri-drustv-18-43) 'Legal Aspects of Companies Restructuring and Transition Towards New Corporate Governance Culture'. The views and opinions of the authors presented in this article are the personal views of the authors and do not reflect the views of the Croatian Financial Services Supervisory Agency.

** Morana Derenčinović Ruk, Croatian Financial Services Supervisory Agency, Zagreb, Croatia; mderencinovic@gmail.com.

**** Mihaela Braut Filipović, University of Rijeka, Faculty of Law, Rijeka, Croatia; mbraut@ pravri.hr.

*** Suzana Audić Vuletić, University of Rijeka, Faculty of Law, Rijeka, Croatia; suzanaav@ yahoo.co.uk. 
limited liability companies be integrated into the capital market law arena, serving as a vessel to investment funds.

KEYWORDS: investment funds with legal personality; Joint-stock and limited liability company as investment funds; investors as shareholders; redemption right

\section{INTRODUCTION}

The investment funds industry is spread throughout the EU Member States. Still, the current trend is that the highest number of the UCITS funds is founded in Luxembourg, and the highest number of the alternative investment funds (further in text: AIF) is founded in Germany. ${ }^{1}$ The regulation of alternative investment funds is left to the Member States. Regardless of their many differences throughout the national legislations, for the application of the Alternative Investment Fund Directive (further in text: AIFMD) ${ }^{2}$, the main criteria are whether they are open-ended or closed-ended funds. Redemption right and its frequency remained the decisive element for determining if the fund is open-ended or closed-ended. As to their advantages to investors, the open-ended funds offer redemption rights while the closed-ended funds primarily offer a less costly investment into illiquid assets and elimination of transaction costs for redeeming shares borne by investors in open-ended funds. In order to make the funds operative, national legislators offered different legal forms and solutions. The aim is to discuss whether the legal status of investment funds is a real yardstick for determining the crucial investor's rights such as redemption rights and relations between the investors and fund managers. Authors shall present the legal solutions from Luxembourg and Germany who both offer open-ended funds in the legal form of the joint-stock company; in order to research whether the legal form of the fund can further influence the choice of the investor as well as the decision of fund managers in which legal form should the fund be established. Authors shall put special focus on the Croatian solutions, especially how can funds established as joint-stock companies be integrated into the capital market law arena, and if the current solutions follow examples from jurisdictions which often serve as role models.

\footnotetext{
1 See Zetzsche, D. A.: The anatomy of European investment fund law, in: Birdthistle, W.A., Morley, J. (eds): Research Handbook on the Regulation of Mutual Funds, Cheltenham, 2018, p. 307. For more accurate data see ESMA Annual Statistical Report, EU Alternative Investment Funds, 2019, [https://www.esma.europa.eu/document/eu-alternative-investment-funds-2019-statistical-report], accessed on 03/07/2020.

2 Directive 2011/61/EU of the European Parliament and of the Council of 8 June 2011 on Alternative Investment Fund Managers and amending Directives 2003/41/EC and 2009/65/EC and Regulations (EC) No 1060/2009 and (EU) No 1095/2010, (OJ L 174, 1/07/2011).
} 


\section{AVAILABLE LEGAL STRUCTURES FOR SETTING UP THE INVESTMENT FUND IN THE EUROPEAN UNION MEMBER STATES}

According to the AIFMD, alternative investment funds are not UCITS funds but are also collective investment undertakings, which raise capital from a number of investors, with a view to investing it in accordance with a defined investment policy for the benefit of those investors. ${ }^{3}$ Besides these cumulative criteria, the European Securities and Markets Authority (further in text: ESMA) argued that an additional factor in determining the AIF should also be that investors have no control or day-to-day discretion regarding the assets of the AIF. ${ }^{4}$ In that, shareholders' voting rights in AIFs established as a company (primarily joint-stock company or Limited Liability Company) should not be considered as having control over the investment strategy of the AIF. ${ }^{5}$

The legal shape in which the AIF is constituted is not decisive. Namely, it is not relevant if AIF is constituted under the law of contract, under the trust law, statute, or has any other legal form. ${ }^{6}$ This should include legal forms as partnerships and foundations as well. ${ }^{7}$ The legal structure of the managers of the AIFs (further in text: AIFM) is also irrelevant. ${ }^{8}$ Further, the AIFMD does not limit AIFs based on the types of assets they choose to invest in or their investment strategies. ${ }^{9}$ Due to the diversity of their investment strategies, there

\footnotetext{
Article 4 (1a) AIFMD. ESMA further analyses these criteria. See ESMA: Discussion paper: Key concepts of the Alternative investment fund Managers Directive and types of AIFM, ESMA/2012/117, February 2012, [https://www.esma.europa.eu/sites/default/files/library/2015/11/2012-117.pdf], accessed on 11/08/2020. UCITS funds are aimed primarily at retail investors, and in order to protect their interest, the EU legislator extensively regulated the UCITS funds. All UCITS fund, regardless of their legal status, can be formed only as open-ended funds with public offerings. See extensively in Braut Filipović, M.: Pravni položaj i odgovornost depozitara UCITS fondova, Rijeka, 2015. On the other hand, AIFs are primarily designed for the institutional investors, and their regulation is left to national legislation of the Member States. On the EU level, only some aspects for managers of AIFs and depositaries are regulated within the AIFMD, while investment strategies and legal frameworks of AIFs greatly vary.
}

4 Ibid., p. 11.

5 See Zetzsche, D. A., Preiner, C. D.: Scope of the AIFMD, in Zetzsche, D. A. (ed.): The Alternative Investment Fund Managers Directive, Alphen aan den Rijn, 2015, p. 75.

6 Article 2 (2b) AIFMD.

7 See Zetzsche, D. A.: The anatomy of European investment fund law, op. cit., p. 340.

8 Article 2(2c) AIFMD. AIFMD's only request is that the AIFM has to be a legal person whose regular bussines is managing one or more AIF.

9 Asset could include for example traditional assets (equity, equity related, debt, etc.) private equity, real estate, and also other non-traditional asset classes such as ships, forests, wine etc., 
are hardly two AIFs that are the same. ${ }^{10}$ Thus, how will the AIF be constituted or classified is left to the Member States according to their national regulations and the need of their economy.

\section{REDEMPTION RIGHT - A TRUE YARDSTICK FOR CHOOSING THE INVESTMENT FUND?}

AIFs could be differentiated in several ways. For example, whether they are open-ended or closed-ended, internally or externally managed, whether they employ leverage and others. However, the most relevant distinction of the AIFs on the EU level for the purpose of differentiating the AIFMs and indirectly AIFs they manage under the AIFMD is whether they are open-ended or closed-ended funds. ${ }^{11}$ These criteria were taken into account in order to ensure that AIFMD is adequately applied regarding the liquidity management and valuation procedures which differ depending on whether the AIF is open-ended or closed-ended.

What is the difference between these two types of AIFs? ESMA issued an opinion in which it elaborated that both open-ended and closed-ended AIFs under the AIFMD can have redemption rights, but the difference is in the frequency of the redemption for the investors. ${ }^{12}$ It further argued that investors perceive a fund as open-ended if they can redeem their shares or units

and any combination thereof. Based on the current AIF's on the European Market ESMA, predicted six types of AIF's according to asset classes: non UCITS funds that invest in asset classes similar to those in which UCITS invest but which do not respect UCITS diversification or leverage requirements; Non UCITS fund that invest in financial instruments that are not eligible assets fot UCITS; Private equity funds; Venture capital funds; real estate funds; alternative investment fund investing in the wide variety of assets including the ships, art, wine, patents, rights, forestry, coins, precious metals, endowment policies, carbon instruments, life sciences and commodities. See ESMA, Discussion paper: Key concepts of the Alternative investment fund Managers Directive and types of AIFM, op. cit.

10 AIFs must repost their investment strategy to the regulator. See Annex IV of Commission Delegated Regulation (EU) No 231/2013 of 19 December 2012 supplementing Directive 2011/61/EU of the European Parliament and of the Council with regard to exemptions, general operating conditions, depositaries, leverage, transparency and supervision, (OJ L 83, 22/03/2013).

11 See ESMA, Consultation paper - Draft regulatory technical standards on types of AIFMs, ESMA 2012/844, 2012, [https://www.esma.europa.eu/sites/default/files/library/2015/11/2012-844.pdf], assessed on 14/10/2020.

12 ESMA, Opinion Draft regulatory tehnical standarts on types of AIFMS under Article 4 (4) of Directive 2011/61/EU, 13 August 2013, [https://www.esma.europa.eu/sites/default/ files/library/2015/11/2013-1119_opinion_on_draft_rts_on_types_of_aifms.pdf], assessed on 15/10/2020, par. 10 and par. 26. 
at least once per year. ${ }^{13}$ On the other hand, the European Commission in its letter to ESMA argued that redemption frequency as criteria for differentiating open-ended from closed-ended AIFs is not in accordance with the AIFMD. ${ }^{14}$ It considered that the criteria should be whether they redeem the investors' shares at all, irrespective of the frequency.

Final solutions were adopted in the Regulation (EU) No. 694/2014. ${ }^{15}$ The Regulation set forth the criteria for both determining the redemption right and the frequency of redemption right for differentiating open-ended and closed-ended funds. When the redemption is taken as a yardstick for differing between open-ended and closed-ended AIFs, it refers to situations when the AIF repurchases the share from the assets of the AIF. ${ }^{16}$ For this purpose, redemption shall not be considered the sale of shares through the secondary market or otherwise. Equally, the same goes for the decrease of the share capital and subsequent return of the payment to investors. ${ }^{17}$ As to the frequency of redemption right, in order to consider an AIF as an open-ended fund, the redemption of shares must be available at the request of the shareholders. This possibility should stay open for investors until the liquidation of the fund in accordance with the frequency which is set in the official documents of the fund (prospectus and others). As to the time limit, Regulation (EU) No. 694/2014 only mentions the five year period as a yardstick, the meaning that if the investor has no right to redeem its shares in the period of five years from the initial investment, the fund shall be qualified as a closed-ended one. ${ }^{18}$

Thus, the frequency of redemption right is taken as a decisive element in differentiating between an open-ended and closed-ended fund for the purpose of the AIFMD, but as a compromise between the ESMA and the European Commission, it is set rather loosely, on the period of five years from the initial offering. Investors of the closed-ended funds usually have the option to sell their shares on the secondary market or otherwise, but as it is not the fund which purchases these units, it cannot be qualified as the redemption of the shares.

\footnotetext{
13 Ibid., par. 12.

14 Letter from the European Commission to the European Securities and Markets Authority concerning draft RTS to determine types of alternative investment fund managers, 4 Jul. 2013, [https://www.esma.europa.eu/sites/default/files/library/2015/11/ec_letter_to_esma_re_draft_ rts_on_types_of_aifmd_4_july_2013.pdf], accessed on 23/10/2020.

15 Commission Delegated Regulation (EU) No 694/2014 of 17 December 2013 supplementing Directive 2011/61/EU of the European Parliament and of the Council with regard to regulatory technical standards determining types of alternative investment fund managers, (OJ L $183,24 / 6 / 2014)$

16 Preambule, par. 4. of the Regulation (EU) No 694/2014.

17 Article 1, par. 2. of the Regulation (EU) No 694/2014.

18 Article 1, par. 5. of the Regulation (EU) No 694/2014.
} 
It is clear that the legal form of the fund is practically irrelevant from the EU legislator's point of view and it is not linked with the definition of open-ended or closed-ended fund which is considered relevant for determining further AIFM's obligations regarding these funds.

From the investor's point of view, besides the redemption policy, investors shall make their choice where to invest depending on the amount of money which they are ready to invest, assets and investment strategy the fund applies, the tax regime on the investment, the liability for the obligation of the fund, the amount of the return which he could expect on the investment and other. ${ }^{19}$

Further, the possibility to influence the management of the fund could also be one of the decisive factors for choosing the fund, especially for professional investors. Investors of the funds with legal personality acquire the membership rights and enter the sphere of company law. Thus, they enjoy shareholders' rights to the extent provided by applicable national law. ${ }^{20}$ However, for investors of open-ended funds, the control rights become even less important in comparison to shareholders in the regular joint-stock company due to their exit right, i.e. their right to redeem the shares. In fact, it is considered that the redemption right itself represents a tool for disciplining fund managers, as they are under constant pressure to ensure that the fund's investments are liquid..$^{21}$ On the other side, the control right and contractual protections become stronger and more important to investors if they don't have effective exit rights. ${ }^{22}$ In other words, control rights are far more important for investors of the closed-ended funds. This is so irrespective of the actual legal form in which the fund is established.

19 See generally Kirk, E.: Open-ended versus closed-ended funds - what's the difference?, Equity, 33 (10) 2019, p. 8; Wegman, H.: Investor protection: towards additional EU regulation of investment funds?, Leiden, 2016, p. 279.

20 Wegman, H., Investor protection: towards additional EU regulation of investment funds?, op. cit., p. 314.

21 Deli, D. N., Varma, R.: Closed-end versus open-end: the choice of organizational form, Journal of Corporate Finance, 8 2002, p. 3. Redemption restrictions could be provided in the contract with the investors. Those protection rights are usually negotiated for the protection of the AIFM that have immediate liquidity. Therefore, investors are willing to wait for some period time for the payment. This is very important for the AIFM - if they do not have this clause negotiated, AIFM has to start the process of liquidation of the AIF regarding the insufficient funds. See Lavoie, G.: Should Private Venture fund Managers import the mutual funds and hedge fund open-ended structure?, Montreal, 2015, p. 9., [https://www.lavery.ca/upload/pdf/ lavoieguillaume/EMBA-FinalPaper-FINAL.PDF], accessed on 13/6/2020.

22 Morley, J.: The Separation of Funds and Managers: A Theory of Investment Fund Structure and Regulation, The Yale Law Journal, 123 (5) 2014, p. 1246, [https://digitalcommons.law. yale.edu/cgi/viewcontent.cgi?article=5621\&context=ylj], accessed on 05/05/2020. 
To conclude, investors shall choose the fund depending on various factors. The prevailing factor is most certainly the redemption right and its frequency. Except for professional investors who typically search for investment in specific assets, possibly illiquid, the control right over the investment process is less relevant for the majority of investors. Authors shall further research whether national law regulations regarding the legal form which supports open-ended or closed-ended funds can further influence the choice of the investor as well as the decision of fund managers in which legal and organizational form should the fund be established.

\section{FUNDS ESTABLISHED IN THE LEGAL FORM OF THE JOINT- STOCK COMPANIES - OPEN-ENDED OR CLOSED-ENDED FUNDS?}

In this chapter authors selected two jurisdictions that are prominent for the investment fund industry in the EU, and which both offer open-ended and closed-ended funds in the legal form of the joint-stock company. The first one is Germany with its Investmentaktiengesellschaft (further in text: Investment-AG), which we follow in its transition from the closed-ended towards the open-end fund ${ }^{23}$ The second is Luxembourg which simultaneously offers Société d'Investissement à Capital Variable (further in text: SICAV) as incorporated investment funds with open-end principle and Société d'Investissement à Capital Fixe (further in text: SICAF), as incorporated investment funds with closed-end principle.

\subsection{ANALYSIS OF GERMAN INVESTMENTAKTIENGESELLSCHAFT FUND - FROM THE CLOSED-ENDED TO AN OPEN-ENDED INVESTMENT VEHICLE}

The possibility to establish the fund in the legal form of the joint-stock company was firstly introduced in 1998 by the KAGG 1998, under the name In-

\footnotetext{
23 In Germany is possible to establish two types of investment funds in the form of a commercial company. The first one is the aforementioned Investment-AG in the legal form of jointstock company with legal personality, while the second is the so-called Investmentkommanditgesellschaft in the legal form of a limited partnership company without legal personality. See Raab, W.: Kapitalverwaltungsgesellschaft (KVG), in: Raab, W., Grundlagen des Investmentfondsgeschäftes, Frankfurt am Main, 2019, p. 34. In this article the focus is put on the Investment-AG, as it also serves as a good comparative example for Croatian closed-end investment funds which can be established in the legal form of a joint-stock company.
} 
vestmentaktiengesellschaft (further in text: Investment-AG). ${ }^{24}$ It had its own legal personality. ${ }^{25}$ The investors of the Investment-AG in KAGG 1998 had no redemption rights, ${ }^{26}$ which meant that this fund was initially a closed-ended investment fund. It was considered that no redemption right shall be particularly advantageous for venture capital funds which often practice longer lock-up periods for their investments. ${ }^{27}$ Thus, German legislator wanted to boost the venture capital industry by creating the Investment-AG which would, hopefully, invest in German companies. ${ }^{28}$ The compromise towards investors was that the shares of the Investment-AG could be offered publicly through the exchange market. ${ }^{29}$ Such a solution should provide investors with the liquidity of their shares on the secondary market. ${ }^{30}$

However, the Investment-AG as regulated by the KAGG 1998 was not successful in practice and not even one was established based upon it. ${ }^{31}$ This was primarily due to the strict requirements for the investment of the capital which limited its investment opportunities in the long term. ${ }^{32}$ Generally, it was perceived that Investment-AG offers no new competitive advantages in comparison to already existing funds without legal personality (Sondervermógen) ${ }^{33}$

24 Dritte Finanzmarktförderungsgesetz, 24/03/1998 (BGBI I S. 529) (further in text: FMFG). The Investment -AG was thus introduced in the Gesetz über Kapitalanlagegesellschaften, 09/09/1998 (BGBI. I S.2726 (further in text KAGG 1998).

25 Gruhn, A. M.: Die deutsche Investmentaktiengesellschaft - Ein Investmentfondsprodukt im Mantel einer Aktiengesellschaft, Berlin, 2011, p. 2.

26 No redemption right for investors stems out from the interpretation of the $\$ 51$ par. 2 of the KAGG 1998.

27 Kaplan, S. N., Stromberg, P.: Leveraged Buyouts and Private Equity, in: Bratton, W.W., McCahery, J.A. (ur.) Institutional Investor Activism, Hedge Funds and Private Equity, Economics and Regulation, Oxford, 2015, str. 493.

28 Thoma, G. G., Steck, K-U., The German Investmentaktiengesellschaft (closed-end fund): Investment Alternative or Legislative Failure?, University of Pennsylvania Journal of International Economic Law, 23 (1) 2002, p. 25.

$29 \S 61$ par. 3 of the KAGG 1998.

30 See Fock, T., Hartig, H., Ist die Investmentaktiengesellschaft überhaupt eine Aktiengesellschaft? In: Wachter, T. (ed), Festschrift für Sebastian Spiegelberger zum 70. Geburtstag, Zerb, 2009, p. 654.

31 See Sachtleber, O. W.: Zivilrechtliche Strukturen von open-end-Investmentfonds in Deutschland und England, Göttingen, 2011, p. 102.

32 See Hermanns, M.: Die Investmentaktiengesellschaft nach dem Investmentmodernisierungsgesetz - eine neue Gesellschaftsform, Zeitschrift für Wirtschaftsrecht, 2004, p. 1297.

33 See Fock, T., Hartig, H., Ist die Investmentaktiengesellschaft überhaupt eine Aktiengesellschaft?, op. cit., p. 655. 
In 2003, German legislator revised the provisions relating to Investment-AG, ${ }^{34}$ where one of the major changes was the introduction of the Investment-AG with variable capital (Investmentaktiengesellschaft mit veränderlichem Kapital). ${ }^{35}$ This represented the revolution in German company law as well, as it introduced some of the fundamental changes in the legal form of the jointstock company for Investment-AG. ${ }^{36}$ The most important change for investors was the introduction of the redemption right,${ }^{37}$ which should make these funds less risky from the investors' point of view. However, the redemption right can be restricted, under the condition that this restriction is regulated in the articles of association of the particular Investment-AG, stating for example that the shares can be redeemed on certain dates only, but at least once quarterly. ${ }^{38}$ The possibility of restricting the redemption right is specifically designed for private equity funds that invest in illiquid assets, such as private companies. ${ }^{39}$

Further, the management of the Investment-AG with variable capital is authorized to continuously issue new shares until the company's share capital reaches the maximum as set in the articles of association, ${ }^{40}$ without the need of prior authorization by the general meeting. It is considered that this authorization is set forth in the articles of association, and thus it is not necessary to obtain it again from the shareholders. ${ }^{41}$ The shareholders don't have the subscription right on new shares. ${ }^{42}$ Also, the company share capital is raised by issuance of new shares, without prior registration of the increase of the share capital as it is necessary for the traditional joint-stock company. ${ }^{43}$ The shares can be issued

\footnotetext{
34 Gesetz zur Modernisierung des Investmentwesens und zur Besteuerung von Investmentvermögen (Investmentmodernisierungsgesetz) (BGBl. I 2003 S. 2676) (further in text: InvG 2003).

$35 \S \S 104-106$ InvG 2003. See also Fromm, A.: Die Investmentaktiengesellschaft mit veränderlichem Kapital, Frankfurt am Main, 2008, p. 16.

36 See Köndgen, J., Schmies, C.: § 113. Investmentgeschäft, in Schimansky, H., Bunte, H-J., Lwowski, H-J. (eds): Bankrechts-Handbuch, München, 2017, Rn 235.

37 See also Hermanns, M.: Die Investmentaktiengesellschaft nach dem Investmentmodernisierungsgesetz - eine neue Gesellschaftsform, op. cit., p. 1300.

38 Loc. cit. See $\$ 116$ of InvG 2003.

39 See Baums, T., Kiem, R.: Die Investmentaktiengesellschaft mit veränderlichem Kapital, Arbeitspapiere, Nr. 118, 2003, Institut für Bankrecht, p. 13, [https://d-nb.info/1059711699/34], accessed on 22/07/2020.

40 See $\S 105$ par. 1 of the InvG 2003.

${ }_{41}$ See also Hermanns, M.: Die Investmentaktiengesellschaft nach dem Investmentmodernisierungsgesetz - eine neue Gesellschaftsform, op. cit., p. 1298.

42 See $\$ 104$ par. 2. of the InvG 2003.

43 See also Köndgen, J., Schmies, C.: § 113. Investmentgeschäft, op. cit., Rn. 236.
} 
only after full payment. ${ }^{44}$ As the ground capital of the Investment-AG is in constant change, it has the obligation to determine the net asset value at least once a week and to publish this data on relevant official registers and relevant newspapers for investors. ${ }^{45}$

However, there were only a few Investment-AG established under the InvG $2003 .{ }^{46}$ It seems that investors were not willing to be the first to use this legal form for conducting investment business and it did not help that the legal framework was considered to be unsatisfactory and fragmented, and not in the line with its role model - the Luxembourgian SICAV (especially regarding the possibility to have external managers). ${ }^{47}$

Thus, further major amendments to Investment-AG were introduced in 2007. ${ }^{48}$ The first most notable difference was that the shares of the Investment-AG were differentiated into two main classes: Unternehmensaktien and Anlageaktien. Holders of Unternehmensaktien are the only ones with the voting rights at the general meeting, ${ }^{49}$ while the holders of the Anlageaktien are passive investors who invest in the Investment-AG with the only goal to obtain profits without the participation in the company as their shareholders. ${ }^{50}$ In other words, most investors cannot influence the decisions of the management of the Investment-AG, as the shareholders of the traditional joint-stock company would be able (regardless of how low this influence could in fact be). On the other hand, the fund initiator or the institutional investor who holds the Unternehmensaktien can influence the management and investment policy of the fund as a shareholder. This can make Investment-AG more attractive to professional investors. Also, it solves the challenge of having passive investors/ shareholders in corporate governance of the incorporated funds, which is a common occurrence in the investment business. ${ }^{51}$ In each case, the distinction between the shares of the Investment-AG leads to the conclusion that the

\footnotetext{
$44 \quad$ See $\$ 103$ par. 1. of the InvG 2003.

45 See $\$ 103$ par. 3. of the InvG 2003.

46 Gruhn, A. M.: Die deutsche Investmentaktiengesellschaft - Ein Investmentfondsprodukt im Mantel einer Aktiengesellschaft, op. cit., p. 8.

47 Steck, K-U., Fisher, C.: Better than SICAV, International Financial Law Review, 29 (1) 2010, p. 58

48 Gesetz zur Änderung des Investmentgesetzes und zur Anpassung anderer Vorschriften (Investmentänderungsgesetz), BGB1. I 2007 S. 3089 (further in text: InvG 2007).

$49 \S 96$, par. 1b of InvG 2007.

50 See Fischer, C., Steck, K-U.: $§ 96$ InvG, in: Berger, H., Steck, K-U. (eds), Investmentgesetz, Investmentsteuergesetz, München, 2010, Rn 3 and further.

51 Spangler, T.: The Law of Private Investment Funds, Third Edition, Oxford, 2018, p. 4
} 
choice of the legal form of funds becomes even less relevant for investors who are not interested in active participation in the incorporated funds. ${ }^{52}$

The second most important change was the introduction of the possibility of external management of the Investment-AG (fremdverwaltete Investmentaktiengesellschaft). ${ }^{53}$ The external manager does not become an organ of the Investment-AG, i.e. it does not replace the management of the Investment-AG. ${ }^{54}$ The introduction of the external manager (the management company or the so-called Kapitalanlagegesellschaft) brings out the question of the potential liability of the external manager towards the Investment-AG and its shareholders. German legal scholars argue that the liability for investment policy and administration remains primarily on the organs of the Investment-AG, and not on the external manager. ${ }^{55}$ It is certainly very interesting to see if in a particular case the shareholders could build a case towards both the management company of the Investment-AG and the external manager. Campbell and Müchler argue that the relationship between Investment-AG and the external manager is contractual, where they qualify the contract as the so-called Geschäftsbesorgungsvertrag. Thus, in their opinion, the liability of the external manager lies in the infringement of the relevant articles of that contract. ${ }^{56}$ One should bear in mind that both Investment-AG with internal or external managers must have a supervisory board, which has a primary role, as in traditional joint-stock companies, to supervise the management of the Investment-AG and to safeguard the interest of the investors/shareholders. ${ }^{57}$

These changes significantly boosted the popularity of Investment-AG with variable capital, as from 2007 till now there were a significant number of them established in Germany. ${ }^{58}$

\footnotetext{
52 See also Köndgen, J., Schmies, C.: § 113. Investmentgeschäft, op. cit., Rn. 234.

$53 \$ 96$ par. 4 of the InvG 2007.

54 See Campbell, N., Müchler, H.: Die Haftung der Verwaltungsgesellschaft einer fremdverwalteten Investmentaktiengesellschaft, Institute for Law and Finance, Working Paper Series No. 101, 04/2009, p. 5., [https://www.ilf-frankfurt.de/fileadmin/_migrated/content_uploads/ ILF_WP_101.pdf], accessed 20/07/2020.

55 See also Köndgen, J., Schmies, C.: § 113. Investmentgeschäft, op. cit., Rn. 228.

56 Campbell, N., Müchler, H.: Die Haftung der Verwaltungsgesellschaft einer fremdverwalteten Investmentaktiengesellschaft, op. cit., p. 3.

57 See Gruhn, A. M.: Die deutsche Investmentaktiengesellschaft - Ein Investmentfondsprodukt im Mantel einer Aktiengesellschaft, op. cit., p. 39.

58 Steck, K-U., Fisher, C.: Better than SICAV, op. cit., p. 58. See also Gruhn, A. M.: Die deutsche Investmentaktiengesellschaft - Ein Investmentfondsprodukt im Mantel einer Aktiengesellschaft, op. cit., p. 12.
} 
Lastly, the Investment-AG with fixed capital has been abolished as it has not been used in practice. ${ }^{59}$ One of the main reasons is that because of the no-redemption rule, investing in such funds was viewed as riskier for the investors, ${ }^{60}$ regardless of the potential liquidity of the shares on the secondary market (via the exchange market).

However, in 2013, the InvG was replaced with the new law - Kapitalanlagegesetzbuch (further in text: KAGB), which is currently in force with some amendments. ${ }^{61}$ The KAGB again introduced the Investment-AG with fixed capital. ${ }^{62}$ Regardless of the fact that it was significantly less popular in practice, some authors argue that it still represents the investment vehicle suitable for private equity and venture capital funds who invest in illiquid assets which makes the redemption right extremely burdensome for the fund. ${ }^{63}$ Thus, currently, under the KAGB, it is possible to establish four company types of investment funds in Germany: Investment-AG with open and closed-end type and Investmentkommanditgesellschaft with open and closed-end type. ${ }^{64}$

In all the legislative changes regarding the Investment-AG with both fixed and variable capital, the German legislator inserted a significant deviance from the traditional joint-stock company. It is a provision abrogating the rule that the articles of association may deviate from the default legal provisions for a joint-stock company only if such a possibility is expressly provided by the law. ${ }^{65}$ By leaving one of the fundamental principles for joint-stock companies, the legislator opened a way to easily introduce changes in the otherwise formidable structure of the joint-stock company in German law. However, by doing so, some authors pose the question as to whether we can designate the Investment-AG as the joint-stock company at all or the legislator has in fact created a completely new legal form when introducing the Investment-AG. ${ }^{66}$

\footnotetext{
59 See Fischer, C., Steck, K-U.: § 96 InvG, op. cit., p. 841.

60 See also Hermanns, M.: Die Investmentaktiengesellschaft nach dem Investmentmodernisierungsgesetz - eine neue Gesellschaftsform,op. cit.,p. 1302.

${ }_{61}$ Kapitalanlagegesetzbuch vom 4. Juli 2013 (BGBl. I S. 1981), das zuletzt durch Artikel 5 des Gesetzes vom 19. März 2020 (BGBl. I S. 529) geändert worden ist.

62 See $\$ \S 140-148$ of the KAGB.

63 See Gruhn, A. M.: Die deutsche Investmentaktiengesellschaft - Ein Investmentfondsprodukt im Mantel einer Aktiengesellschaft, op. cit., p. 70.

${ }^{64}$ See Köndgen, J., Schmies, C.: § 113. Investmentgeschäft, op. cit., Rn. 224.

65 See $\S 108$ par. 2 and $\S 140$ par. 2 of the KAGB abrogating the $\S 23$ par. 5 of the Aktiengesetz (Aktiengesetz vom 6. September 1965 (BGBl. I S. 1089), das zuletzt durch Artikel 1 des Gesetzes vom 12. Dezember 2019 (BGB1. I S. 2637) geändert worden ist).

66 See Fock, T., Hartig, H., Ist die Investmentaktiengesellschaft überhaupt eine Aktiengesellschaft?, op. cit., p. 659.
} 
It is clear that the company law and the capital market law for Investment-AG are overlapping. However, the KAGB is the lex specialis for investment funds. ${ }^{67}$ The Investment-AG is the child of capital market law, where we primarily analyze all the specifics relating to the investment business, while its legal form of the joint-stock company comes into consideration as of secondary importance.$^{68}$ For example, one of the major differences between the traditional German joint-stock company and the Investment-AG is the redemption right of the investors (for Investment-AG with variable capital) and the possibility of external management. Thus, the authors are free to conclude that in practice it is difficult to draw conclusions regarding the investment funds and the position of its investors/shareholders by analyzing the legal forms of the incorporated funds solely. One should primarily take into account all the specifics of the investment business, as in the authors' opinion, it takes precedence over the chosen form of the investment fund.

\subsection{ANALYSIS OF LUXEMBOURG SICAV AS AN EXAMPLE OF AN OPEN-ENDED FUND WITH VARIABLE CAPITAL IN THE LEGAL FORM OF THE JOINT-STOCK COMPANY}

Luxembourg is today one of the most prominent centers for the investment fund industry in Europe. The first open-ended incorporated investment fund was founded in 1959. ${ }^{69}$ The development of open-ended incorporated funds can be traced through several legislative changes. In 1983 Luxembourg adopted the first law which nominated the existing open-end incorporated fund in the legal form of the joint-stock company as SICAV. ${ }^{70}$ This law was subsequently replaced in 1988 (further in text: Loi 1988) (11 $^{\text {, in }} 2002$ (further in text:

\footnotetext{
67 See $\$ 108$ par. 2 of the KAGB.

68 See also Köndgen, J., Schmies, C.: § 113. Investmentgeschäft, op. cit., Rn. 225. See also Gruhn, A. M.: Die deutsche Investmentaktiengesellschaft - Ein Investmentfondsprodukt im Mantel einer Aktiengesellschaft, op. cit., p. 32.

69 Rounds, C. E., Dehio, A.: Publicly-Traded Open End Mutual Funds in Common Law and Civil Jurisdictions: A Comparison of Legal Structures, New York University Journal of Law \& Business, 3 (2) 2007, p. 501. The first investment funds were not even regulated by the law, but rather by decisions of the Ministry of Finance, through Décisions du ministre des Finances $d u$ 13 février 1959 et du 9 février 1960. For development of the Luxembourg investment funds see also Elvinger, J., Schmit, I. M. : Les Sociétés de Gestion d'organismes de Placement Collectif en Droit Luxembourgeois, Droit bancaire et financier au Luxembourg, 4 2004, p. 1497.

70 Art. 44 of the Loi du 25 août 1983 relative aux organismes de placement collectif.

71 Loi du 30 mars 1988 relative aux organismes de placement collectif
} 
Loi 2002) $)^{72}$ and the current law concerning the investment funds is the Loi $d u$ 17 décembre 2010 concernant les organismes de placement collectif(further in text: Loi 2010), with the latest amendment in 2019. ${ }^{73}$

Both SICAV and SICAF have a legal personality. However, while the SICAV can be established in the legal form of the joint-stock company (société anonyme) or Societas Europaea only, the SICAF can be established in many legal forms, most often as a joint-stock company, limited liability company, or limited partnership. ${ }^{74}$ Thus, SICAF is a term that relates to all types of closedend incorporated investment funds. As the term SICAF is too general, it is used in legal theory but not in the legal sources. Investment funds that fall in the category of SICAFs are closer to traditional legal forms of commercial companies, with fewer deviances from the company law. ${ }^{75}$ In other words, in practice, that means that SICAFs are perceived as less liquid investment funds, as they more often do not provide a redemption right to the investors. In this article, the authors shall put the accent on the analysis of SICAV, which can be established in the legal form of the joint-stock company only, for the purpose of comparison to German Investment-AG and Croatian AIF in the form of the joint-stock company.

Luxembourg provisions applying on SICAV have remained in the most part the same throughout all the legislative changes, which means that the Luxembourg legislator achieved to create a very popular investment vehicle from the beginning of its introduction. Thus, it is of no surprise that it served as a role model for German Investment-AG with variable capital. ${ }^{76}$ The most important common feature is that investors have the right to redeem their shares, where possible restrictions of redemption can be introduced only in the articles of the association of the SICAV..$^{77}$ The share capital is constantly changing due to emission of the new shares and redemption on demand, but the change of the share capital is automatically done, without the need to publish the new

72 Loi du 20 décembre 2002 concernant les organismes de placement collectif et modifiant la loi modifiée du 12 février 1979 concernant la taxe sur la valeur ajoutée.

73 Loi du 8 avril 2019 relative à des mesures à prendre en relation avec le secteur financier en cas de retrait du Royaume-Uni de Grande-Bretagne et d'Irlande du Nord de l'Union européenne et modifiant: $1^{\circ}$ la loi modifiée du 13 février 2007 relative aux fonds d'investissement spécialisés; et $2^{\circ}$ la loi modifiée du 17 décembre 2010 concernant les organismes de placement collectif.

${ }^{74}$ Kremer, C., Lebbe, I.: Organismes De Placement Collectif et Véhicules d'investissement apparentés en droit luxembourgeois, Larcier, 2007, p. 89.

$75 \quad$ Ibid., p. 278.

76 See also Köndgen, J., Schmies, C.: § 113. Investmentgeschäft, op. cit., Rn. 235.

77 See art. 27 of the Loi 1988., art. 28 of the Loi 2002. and art. 28 of the Loi 2010. 
amounts of share capital in official registers as would be the case for traditional joint-stock companies. Also, no prior authorization by the general meeting is necessary. ${ }^{78}$ Investors/shareholders don't have subscription rights on the new shares. ${ }^{79}$ SICAV, under the condition it is an umbrella fund, can issue shares with different values, which is yet another exception from the Luxembourg company law. ${ }^{80}$

SICAV is subject to the application of both company law provisions regarding the joint-stock company and capital market law governing the investment vehicles. However, as in the case of Germany, company law provisions ${ }^{81}$ apply only as lex generalis, where investment funds law has an advantage and can derogate company law provisions. ${ }^{82}$ Thus, as already demonstrated, many company law provisions for the joint-stock company are derogated.

SICAV which has an external manager still has its own management as other joint-stock companies. The SICAV's management can delegate the daily management of the company and the investments, administrative tasks, and others, but it cannot fully delegate its powers to third persons. ${ }^{83}$ Depending on the extent of the delegation, it retains certain tasks as the approval of concluding certain contracts, supervision over the management of the company's assets, and others. However, regardless of the delegation of various management tasks, their liability towards investors/shareholders and third persons practically remain the same. ${ }^{84}$ Thus, the fact that the SICAV is externally managed, does not exclude the SICAV's management of the liability that managers usually have in the traditional joint-stock companies. On the other hand, external managers are liable primarily towards the SICAV based on their contract, which is in theory primarily classified as a contrat de mandat. ${ }^{85}$

Redemption, i.e. liquidity of the shares proves to be an important factor for investors of Luxembourg SICAV and SICAF. Despite the fact that shares of SICAF can be traded on the exchange market, the SICAV remain the most

\footnotetext{
78 Kremer, C., Lebbe, I.: Organismes De Placement Collectif et Véhicules d'investissement apparentés en droit luxembourgeois, op. cit., p. 277.

79 See art. 28 of the Loi 1988., art. 29 of the Loi 2002. and art. 29 of the Loi 2010.

80 Kremer, C., Lebbe, I.: Organismes De Placement Collectif et Véhicules d'investissement apparentés en droit luxembourgeois, op. cit., p. 251.

81 Loi du 10 août 1915 concernant les sociétés commerciales.

82 See art. 25 of the Loi 1988., art. 26 of the Loi 2002. and art. 26 of the Loi 2010.

83 Kremer, C., Lebbe, I.: Organismes De Placement Collectif et Véhicules d'investissement apparentés en droit luxembourgeois, op. cit., p. 319.

${ }^{84} \quad$ Ibid., p. 366.

$85 \quad$ Ibid., p. 375.
} 
popular investment vehicle in practice. ${ }^{86}$ This follows the conclusion for German investment vehicles, where Investment-AG with variable capital as the open-end incorporated funds is far more attractive to investors than Investment-Ag with fixed capital.

\section{INVESTORS AS SHAREHOLDERS - SOME OPEN ISSUES}

Corporate governance of the incorporated fund is often a neglected topic. The relation between investors/shareholders and the management of the incorporated fund is an open issue. Their relation primarily depends on the type of the company which serves as a legal vehicle for the fund and applicable national legislation. The last may significantly vary regarding the national provisions for alternative investment funds and regarding the company law, as both areas are predominantly left to the national legislation of the EU Member States. ${ }^{87}$

The control right of the investors is primarily expressed through their voting right on the general meeting where they are able to express their discontent with the management of the fund, but except in cases when the investors are major shareholders, influence through voting rights cannot be considered as an effective tool of investors' protection. ${ }^{88}$ For open-ended funds, as argued previously, the redemption right itself can serve as the best tool of control over managers.

It is a common practice that incorporated funds, particularly the German Investment-AG and the Luxembourg SICAV, ${ }^{89}$ have an external manager. That brings out the question of whom and to which extent safeguards the interest of investors - fund's management or the external manager, and the scope of the duties still retained by the management. The answer depends on the national regulation where the incorporated fund is founded, in particular, upon the legal nature of the relation between the management and the external manager and the issue of liability towards investors.

\footnotetext{
86 Guide de l'investisseur, Instruments financiers, [https://www.ing.lu/webing/content/ dam/ing/PDF/personal/invest/investor-guide/guide_de_l_investisseur_fr.pdf], accessed on 03/09/2020, p. 9 .

87 The AIFMD regulated managers, but leaves the regulation of alternative investment funds to national regulators. As to the EU company law, only some aspects of the companies are harmonised, primarily relating to joint-stock companies. For advantages and disadvantages of the harmonisation of the EU company law see in Grundmann, S.: European Company Law, Organisation, Finance and Capital Markets, Antwerpen-Oxford, 2007, p. 96.

88 Wegman, H., Investor protection: towards additional EU regulation of investment funds?, op. cit.,p. 274.

89 Steck, K-U., Fisher, C.: Better than SICAV, op. cit., p. 58. Also, all Croatian incorporated funds have external managers.
} 
Generally, the role of the management in incorporated funds is controversial. It is argued that there are significant differences in comparison to the role and duties of management in traditional joint-stock companies. ${ }^{90}$ Some even argue that investment funds should be regarded as products, and not as legal entities for which one should consider challenges of governance at all. ${ }^{91}$

We can also discuss whether it is better for the interest of the investors to have managers of the fund who are independent of the external manager. ${ }^{92}$ For starters, that would mean that the managers of the fond and the external managers are different persons. The potential benefit of independent managers would certainly be the representation of investors' interest, negotiation of management fees, and others. In the authors' opinion, the composition of the management of the incorporated fund is of crucial meaning for promoting and representing the interests of investors/shareholders in the incorporated funds.

On the other hand, it is an open issue whether investors/shareholders have the duty to act in the interest of the company (the incorporated fund) at all. This is due to the request that the investment fund (or its management company) must act in the interest of the investors, and presumably surpass the interest of the fund, which is a legal standard inserted through the EU legislation and thus present in the legislations of all the Member States. ${ }^{93}$ In other words, the interest of the incorporated fund in the form of the joint-stock company becomes irrelevant in comparison to the interest of its investors/shareholders. If the management must be oriented towards the interest of the shareholders, then it would be very hard to argue that investors/shareholders should not act in self-interest, but in the interest of the fund/company. Such findings drastically differ from the traditional rethinking of the corporate governance in jointstock companies, and further evidence that the position of investors should not be equaled to the position of a shareholder, regardless of the legal form of the incorporated fund.

Finally, most countries have developed corporate governance codices for companies that trade publicly on the exchange market. In the authors' opinion, these

90 Johnson, L. P. Q., Protecting mutual fund investors: an inevitable eclecticism, in: Birdthistle, W. A., Morley, J. (eds), Research Handbook on the Regulation of Mutual Funds, Cheltenham, 2018, p. 151.

91 For an overview see Krig, A. K.: Toward better mutual fund governance, in Birdthistle, W. A., Morley, J. (eds): Research Handbook on the Regulation of Mutual Funds, Cheltenham, 2018, p. 186.

92 Spangler, T.: The Law of Private Investment Funds, op. cit., p. 261.

93 Zetzsche, D.: Das Gesellschaftsrecht des Kapitalanlagegesetzbuches, Die Aktiengesellschaft, 17 2013, p. 615. See also Gruhn, A. M.: Die deutsche Investmentaktiengesellschaft - Ein Investmentfondsprodukt im Mantel einer Aktiengesellschaft, op. cit., p. 35. 
codices should apply to incorporated funds which are listed on the exchange market as well, ${ }^{94}$ as the protection of possible investors is equally needed when both the traditional joint-stock company and the investment fund incorporated as a joint-stock company offer their shares to the public on the exchange market. For example, Croatian incorporated funds that are listed on the exchange market are obliged to apply the Corporate governance code. ${ }^{95}$ Being listed on the exchange market brings at least two benefits to the investors/shareholders. The first one is the supervision that the rules of the exchange market are followed which by itself helps in enhancing the corporate governance of the incorporated fund. The other is the liquidity of the shares achieved by secondary trading, where the liquidity heavily depends on the market itself. ${ }^{96}$

On the other side, incorporated funds with the private placement are off the grid completely. In the authors' opinion, legislators should put a bigger focus on the issues of corporate governance of all incorporated funds, as they represent specific legal vehicles that more often than not significantly deviate from the regulation for traditional legal forms in which they are incorporated.

\section{CROATIAN PERSPECTIVE}

The Croatian experience is determined by the development of fund regulations, which began in 1995 with the adoption of the first Investment Funds Act [further in text: IFA 1]. ${ }^{97}$ IFA 1 distinguished open-ended funds, which were a separate pool of assets without legal personality, and closed-ended funds, which could only be established as a joint-stock company whose shares are registered and unlimitedly transferable, and the fund can't issue preferred shares or shares with different rights. ${ }^{98}$ A closed-ended fund had a management board with two members, appointed by the management company, and a supervisory board whose members jointly represent the closed-ended fund towards the management company. ${ }^{99}$ According to the provisions of IFA 1, no closed-ended funds were ever established in Croatia, but in 1997 a special Law

\footnotetext{
94 See also Spangler, T., The Law of Private Investment Funds, op. cit., p. 9.

95 Croatian Corporate governance code, [https://zse.hr/UserDocsImages/legal/Corporate $\% 20$ Governance\%20Code-eng2010.pdf], accessed on 03/09/2020.

96 See also Spangler, T., The Law of Private Investment Funds, op. cit., p. 280.

97 Investment Funds Act was amended twice - in 1996 and 2001 - Official Gazzette 107/95, $12 / 96$ and 114/01.

98 Article 39. and article 43. IFA 1.

99 Article 46. IFA 1.
} 
on Privatization Investment Funds was passed [further in text: LPIF], ${ }^{100}$ which enabled the establishment of privatization funds, also in the form of joint-stock companies and on the basis of which numerous privatization funds were established in Croatia. Privatization funds were managed by management companies in accordance with LPIF and IFA 1, which appointed the management and the first supervisory board of the privatization funds, and were established for a fixed period of time (five years) after which time they had to be transformed into "classic" closed-ended funds according to IFA 1. Neither IFA 1 nor LPIF specifically regulated the rights of shareholders of closed-ended funds, so provisions of the Companies $\mathrm{Act}^{101}$ were applied in that matter as a lex generalis.

In 2005, a new Law on Investment Funds [further in text: IFA 2] was adopted, ${ }^{102}$ which transposed the UCITS III directive into Croatian legislation, and which distinguished between open-ended investment funds as a separate pool of assets without legal personality (they could be established as an open-ended investment fund with a public offering, ${ }^{103}$ an open-ended investment fund with a private offering and open-ended private equity fund with a private offering) and closed-ended investment fund as funds with a public offering. ${ }^{104}$ For all these fund types, IFA 2 prescribed fairly detailed permitted investments limitation on investment.

A closed-ended investment fund with a public offering once again had to be established as a joint-stock company that can issue only ordinary registered shares, granting shareholders equal rights, as provided for by the law, prospectus, and fund rules, and may not issue any other type of securities. ${ }^{105}$ This time, IFA 2 proscribed that the shares of the closed-ended investment fund with a public offering shall be admitted to official listing on the stock exchange or another regulated market open to the public. ${ }^{106}$ IFA 2 has prescribed in great detail the membership of the fund's supervisory board and its competence ${ }^{107}$ so the supervisory board members, in addition to the competence of the super-

100 Official Gazzette 109/97 and 114/01. Seven privatization investment funds were established: Sunce zif d.d., Velebit zif d.d., Dom Holding zif d.d., Središnji nacionalni fond zif d.d., Pleter zif d.d., Expandia zif d.d. i Slavonski zif d.d.

101 Companies Act, Official Gazette, Nos. 111/93, 34/99, 121/99, 52/00, 118/03, 107/07, 146/08, 137/09, 125/11, 152/11, 111/12, 68/13, 110/15, 40/19.

102 Official Gazzette 150/05.

103 UCITS fund was open-ended investment fund with a public offering, all others were alternative investment funds.

104 Article 2. IFA 2.

105 Article 60. and article 64. IFA 2.

106 Article 64. IFA 2.

107 Articles 69. - 75. IFA 2. 
visory board granted under the Companies Act, jointly represented the fund in relation to the management company. Besides, IFA 2 explicitly prescribed various oversight duties of the supervisory board. ${ }^{108}$ The question of fund management was foreseen in a very interesting and controversial way - the management board of the management company had the authority, was appointed and acted as the management board of the fund, and managed the fund in accordance with the contract concluded between the management company and the fund. ${ }^{109}$ The supervisory board represents the fund when concluding this contract.

As far as shareholder rights are concerned IFA 2 prescribed that the Companies Act shall apply on the competence, convening, and holding of the general meeting. However, the general meeting may make valid decisions only if votes representing at least $3 / 10$ of the registered capital of the fund are present at the general meeting. ${ }^{110}$ The general meeting also had the right to make specific decisions (based on the votes representing at least three-quarters of the registered capital, present at the fund's general meeting at the time of decision making): increase in the annual fee to the management company, change in investment objectives of the fund (concerning the objectives indicated in the prospectus), acquisition of fund's own shares for the purpose of their redemption, the extension of the fund's operation relative to the period indicated in the prospectus, merger into and consolidation with another fund, i.e. division of the fund. ${ }^{111}$

IFA 2 also provided special rules for real estate funds, which could only be established as closed-ended funds with a public offering for investment in real estate, and had to invest more than $60 \%$ of the fund's net asset value in real estate. $^{112}$

It is evident from the above-listed competencies of the funds' general meeting and supervisory board that IFA 2 gave investors/shareholders significantly greater powers regarding issues that fall within direct fund management, i.e. issues that directly affect them. In that period, several closed-ended funds were established in Croatia, but only as real estate funds - Quaestus nekret-

108 For example supervision over the compliance of business operations, as well as the objectives and limitations on investment of an individual fund (!), approving of decisions concerning the share redemption, share issue and fund restructuring at the fund's general meeting, communication with the Supervisory Authority any failure of to comply with IFA 2 and relevant regulations.

109 Article 76. IFA 2.

110 Article 85. IFA 2.

111 Article 86 IFA 2.

112 Article 80. IFA 2. 
nine d.d., ZAIF Proprius d.d., Jadran Kapital d.d., while the privatization funds Slavonski ZAIF d.d. and Velebit d.d. harmonized their business operations with IFA 2, as well as was with ZAIF Breza d.d., and continued to operate as closed-ended funds.

With Croatia's accession to the EU in 2013, the legislative environment was significantly changed and improved, and since then there are two laws governing investment funds - Open-ended Investment Funds with Public Offering Act (further in text: IFPOA 1) ${ }^{113}$ which regulates UCITS funds, and the Alternative Investment Funds Act (further in text: AIFA 1), ${ }^{114}$ which, unlike many EU laws implementing the AIFMD, regulates both management companies (AIFM) and AIFs. During this period, many closed-ended funds ceased to exist due to the transitional provision of AIFA 1 which stipulated that closed-ended investment funds with a public offering established under provisions of IFA 2 , which are undergoing the winding-up procedure on the day of the adoption of AIFA 1, and the winding-up procedure is not completed by the entry into force of AIFA 1, shall no longer be investment funds within the meaning of the provisions of AIFA $1 .{ }^{115}$

Unfortunately, Croatia then continued on the path set by IFA 1 and IFA 2 in relation to the definition of closed-ended funds. AIFA 1 wrongly defined closed-ended fund as a legal person established in the form of a joint-stock company or a limited liability company, which is established by an AIFM and managed by an AIFM on behalf and for the account of the AIF, the units of which are not redeemable on unit-holders' request out of the assets of the closed-ended AIF. ${ }^{116}$ Improvement can be seen in the fact that in addition to a joint-stock company, the possibility of establishing a closed-end fund in the form of a limited liability company has been added, but again, unfortunately, other much more appropriate forms have not been recognized, such as a limited partnership, which corresponds much better to private equity funds. As

113 Official Gazzette Nos. 16/2013, 143/2014. Today Open-ended Investment Funds with Public Offering Act (further in text: IFPOA 2) is in force, Official Gazzette 44/2016 i 126/2019.

114 Official Gazzette 16/2013 and 143/2014. Today Alternative Investment Funds Act (further in text:AIFA 2) is in force, Official Gazzette 21/2018.

115 Article 325. AIFA 1.

116 Article 3. AIFA 1. Open-ended AIF on the other hand means a separate pool of assets, without legal personality, constituted by an AIFM and managed by the AIFM in its own name and for the joint account of holders of units in such assets in accordance with the provisions of this Act, the prospectus and/or the fund rules. Open-ended AIFs may be managed by an external AIFM only. Units in an open-ended AIF are, at the request of unit-holders, redeemed, directly or indirectly, out of the assets of the open-ended AIF in the manner and under the conditions laid down in the prospectus and/or the fund rules. An open-ended AIF may have legal personality if that is allowed by national law of a Member State or a third country. 
previously discussed, the basic criterion for distinguishing open-ended from closed-ended AIFs is redemption policy, not the legal personality of the AIF, which is expressly stated in the relevant EU documents. ${ }^{117}$

The dualism of laws applicable to closed-ended funds has continued, where the Companies Act applies to closed-ended AIFs as lex generalis and AIFA 1 as lex specialis. ${ }^{118}$ Shares of a closed-ended AIF can be issued in a dematerialized form only and they give shareholders the rights established by both the Companies Act and AIFA 1, the prospectus of the fund where applicable, the rules of the fund, and the articles of association of the fund. ${ }^{119}$

The supervisory board of the closed-ended funds received an additional competence - carrying on the activities related to the compulsory transfer of management of a closed-ended AIF to another AIFM, ${ }^{120}$ while the relationship between the AIFM and the fund management got more complicated. AIFA 1 prescribed that a closed-ended AIF established as a joint-stock company with an external AIFM shall not have the management, because the obligations and powers of the traditional management board were imposed and conferred on the management board of an AIFM which manages the closed-ended AIF. ${ }^{121}$ The AIFM managed the operations of a closed-ended AIF and represented it with regard to all matters, except for those where the supervisory board of a closed-ended AIF is empowered for the representation of the closed-ended AIF. AIFA 2 in 2018 confirmed the same solution. ${ }^{122}$

The general meeting also received new powers - not only the change of investment objectives but also the risk profile of the fund; decision on the termination before the termination date defined in the AIF rules or the extension of the operation of the fund established for a fixed period of time; termination of the management agreement entered into with an AIFM; the liquidation of an AIF and granting approval for the supervisory board's decision on the transfer of management functions to another AIFM. ${ }^{123}$

Further improvement in this area was achieved in 2018, with the introduction of the possibility of establishing closed-ended funds with legal personality (still only as a joint-stock company or a limited liability company) and without legal personality, as a separate pool of assets whose shares are not redeemable

\footnotetext{
See Chapter 3 of this Article.

118 Article 112 AIFA 1.

119 Article 113 AIFA 1.

120 Article 121. AIFA 1.

121 Article 115. AIFA 1.

122 Article 100 AIFA 2.

123 Article 123. AIFA 1.
} 
from AIF assets at the request of investors. ${ }^{124}$ The first Croatian closed-ended fund without legal personality was established in October 2020.

Currently, there are only four closed-ended AIFs with legal personality in Croatia: Kapitalni fond d.d., ZAIF Proprius d.d., ZAIF Breza d.d., and Slavonski ZAIF d.d., while ZAIF Proprius d.d. is in the process of liquidation from April 2020. All of these funds are established in the legal form of joint-stock companies, for two reasons:

1. either they were established in the period of establishment of privatization funds

2. either they were established in the period from 2006 to 2008, and then exclusively as closed-ended real estate funds (that was the period of great real estate boom in Croatia),

and in both cases, legislative framework allowed the establishment of closed-ended funds with a legal personality only in the form of joint-stock companies, not a limited liability company. Afterwards, not a single closed-ended fund with legal personality was established in Croatia, and only recently (October 2020) one fund was established as a closed-ended fund - but this is the fund without legal personality and with private placement (private equity fund).

There can be several reasons for this situation, for starters it is easier to raise significantly larger funds from the public (i.e. retail investors, that's why those funds were all with public offering), so ZAIF Proprius raised HRK 60 million, Quaestus Nekretnine raised as much as HRK 225 million, and Jadran Kapital HRK 79 million, while on the other hand, recently established umbrella fund with the public offering (but without legal personality) Fima Invest Funds with its two sub-funds (Fima Global Income Builder and Fime SEE Income Builder) raised only HRK 10 million. Also, the costs of establishing and operating funds with legal personality are higher (costs of depositories and stock exchange...), before explained dualism of management is present, as well as the greater influence of shareholders on the operation of the fund.

Therefore, de lege ferenda, it would be good and useful to allow the establishment of funds with legal personality in the form of a limited partnership (komanditno društvo), which form is the most common in the world when it comes to $\mathrm{PE} / \mathrm{VC}$ funds. That would be, by all means, a significant generator of the $\mathrm{PE} / \mathrm{VC}$ market in Croatia and economic development and progress of the companies in which those funds invest (mostly SMEs, start-ups...).

Finally, the current investment fund industry is also under influence of the COVID-19. The influence of COVID-19 on the Croatian investment fund indus-

124 Article 4. AIFA 2. 
try is best shown from the following figures ${ }^{125}$ - from 1/3/2020 to 30/6/2020 NAV of Croatian UCITS funds decreased from HRK 23,070 billion to HRK 16,028 billion (HRK 7,042 billion) - the decrease of HRK 6,661 billion refers to the net exits of investors from UCITS funds, while the rest of the decrease (HRK 381 million) refers to the negative market impact. Thus, in Croatia, the COVID-19 crisis primarily affected UCITS funds. Authors argue that these findings correspond to the primacy of numbers of UCITS funds in the Croatian market in comparison to AIFs, and especially in relation to the closed-ended AIFs.

\section{CONCLUSION}

Closed-ended funds are present in the fund industry, although in lower numbers than open-ended, i.e. mutual funds. It seems that redemption right is crucial for the majority of investors when choosing the fund. The most prominent centers for AIFs in Europe, Germany, and Luxembourg, both introduced the joint-stock company as the legal form in which closed-ended, and later open-ended funds could be established. However, in the German example, the Investment $\mathrm{AG}$ as the $\mathrm{AIF}$ in the legal form of the joint-stock company did not become popular in practice until it has introduced the redemption right, i.e. until it became the open-ended fund.

From the legal perspective, however, the legal form in which the fund is established is significant for determining the position of investors, and the corporate governance of the fund. Even in cases when the fund is incorporated as a jointstock company, it is questionable whether we can completely line up investors with shareholders. Both German Investment-AG and Luxembourg SICAV significantly deviate from the traditional legal form of the joint-stock companies. Thus, in the authors' opinion, corporate governance of investment funds and the position of its investors should be regarded as a new form of corporate governance which only partially overlaps with the challenges in traditional joint-stock companies.

Croatian perspective shows that Croatian legislative framework from the very beginning made the wrong distinction between open-ended and closed-ended funds, allowing only legal entities (first joint-stock company, and then limited liability company) to be founded as closed-ended funds, i.e. looking at their form and not the essence (whether investors can ask for the redemption of their units at any time or is that right (significantly) limited (and how)). This continued until 2018, since when it is possible to establish closed AIFs without legal personality, and in October 2020 one such AIF was founded

125 See HANFA, [https://www.hanfa.hr/], accessed on 9/11/2020. 
(private equity fund). From the investors' perspective, they have greater rights and opportunities to influence fund operations and its fate (investment strategy, risks, duration, mergers, fund, etc.) if a fund is formed in the legal form of the joint-stock company, because of the various rights company law gives them (via shareholders meetings, supervisory board, etc.), as well as specific rights all investors have via investment funds legislation. Investors in Croatian open-ended funds have no such rights, all they can do if they don't like the way the fund is managed is leave.

However, there are only four AIFs established as a joint-stock company in Croatia, which clearly states that the current legislative framework for these funds is unattractive. In the authors' opinion, the Croatian legislature should de lege ferenda introduce new legal forms for AIFs, such as limited partnerships which are considered one of the most popular legal forms for investment business in comparative jurisdiction. Also, authors call for a revision of the provisions regulating the joint-stock company for AIFs in Croatia, especially regarding the relationship between the management of the AIF and the external managers and the possibility to introduce a joint-stock company with variable capital, where German Investment-AG and Luxembourg SICAV can serve as a role model.

\section{LITERATURE}

1. Alternative Investment Funds Act, Official Gazzette Nos. 16/2013, 143/2014.

2. Alternative Investment Funds, Official Gazzette No. 21/2018.

3. Aktiengesetz vom 6. September 1965 (BGBl. I S. 1089), das zuletzt durch Artikel 1 des Gesetzes vom 12. Dezember 2019 (BGBl. I S. 2637) geändert worden ist.

4. Baums, T., Kiem, R.: Die Investmentaktiengesellschaft mit veränderlichem Kapital, Arbeitspapiere, Nr. 118, 2003, Institut für Bankrecht, [https://d-nb. info/1059711699/34], accessed on 22/07/2020.

5. Braut Filipović, M.: Pravni položaj i odgovornost depozitara UCITS fondova, Rijeka, 2015.

6. Campbell, N., Müchler, H.: Die Haftung der Verwaltungsgesellschaft einer fremdverwalteten Investmentaktiengesellschaft, Institute for Law and Finance, Working Paper Series No. 101, 04/2009, [https://www.ilf-frankfurt.de/fileadmin/_migrated/content_uploads/ILF_WP_101.pdf], accessed 20/07/2020.

7. Commission Delegated Regulation (EU) No 231/2013 of 19 December 2012 supplementing Directive 2011/61/EU of the European Parliament and of the Council with regard to exemptions, general operating conditions, depositaries, leverage, transparency and supervision, (OJ L 83, 22/03/2013). 
8. Commission Delegated Regulation (EU) No 694/2014 of 17 December 2013 supplementing Directive 2011/61/EU of the European Parliament and of the Council with regard to regulatory technical standards determining types of alternative investment fund managers, (OJ L 183, 24/6/2014).

9. Companies Act, Official Gazette, Nos. 111/93, 34/99, 121/99, 52/00, 118/03, 107/07, 146/08, 137/09, 125/11, 152/11, 111/12, 68/13, 110/15, 40/19.

10. Croatian Corporate governance code, [https://zse.hr/UserDocsImages/legal/Corporate\%20Governance\%20Code-eng2010.pdf], accessed on 03/09/2020.

11. Deli, D. N., Varma, R.: Closed-end versus open-end: the choice of organizational form, Journal of Corporate Finance, 82002.

-DOI: https://doi.org/10.1016/S0929-1199(01)00038-4

12. Directive 2011/61/EU of the European Parliament and of the Council of 8 June 2011 on Alternative Investment Fund Managers and amending Directives 2003/41/EC and 2009/65/EC and Regulations (EC) No 1060/2009 and (EU) No 1095/2010, (OJ L 174, 1/07/2011).

13. Dritte Finanzmarktförderungsgesetz, 24/03/1998 (BGBI I S. 529).

14. Elvinger, J., Schmit, I. M.: Les Sociétés de Gestion d'organismes de Placement Collectif en Droit Luxembourgeois, Droit bancaire et financier au Luxembourg, 42004.

15. ESMA Annual Statistical Report, EU Alternative Investment Funds, 2019, [https:// www.esma.europa.eu/document/eu-alternative-investment-funds-2019-statistical-report], accessed on 03/07/2020.

16. ESMA, Consultation paper - Draft regulatory technical standards on types of AIFMs, ESMA 2012/844, 2012, [https://www.esma.europa.eu/sites/default/files/ library/2015/11/2012-844.pdf], assessed on 14/10/2020.

17. ESMA: Discussion paper: Key concepts of the Alternative investment fund Managers Directive and types of AIFM, ESMA/2012/117, February 2012, [https:// www.esma.europa.eu/sites/default/files/library/2015/11/2012-117.pdf], accessed on $11 / 08 / 2020$.

18. ESMA, Opinion Draft regulatory tehnical standarts on types of AIFMS under Article 4 (4) of Directive 2011/61/EU, 13 August 2013, [https://www.esma.europa.eu/sites/default/files/library/2015/11/2013-1119_opinion_on_draft_rts_on_ types_of_aifms.pdf], assessed on 15/10/2020.

19. Fischer, C., Steck, K-U.: $§ 96$ InvG, in: Berger, H., Steck, K-U. (eds), Investmentgesetz, Investmentsteuergesetz, München, 2010.

20. Fock, T., Hartig, H., Ist die Investmentaktiengesellschaft überhaupt eine Aktiengesellschaft? In: Wachter, T. (ed), Festschrift für Sebastian Spiegelberger zum 70. Geburtstag, Zerb, 2009.

21. Fromm, A.: Die Investmentaktiengesellschaft mit veränderlichem Kapital, Frankfurt am Main, 2008. 
22. Gesetz über Kapitalanlagegesellschaften, 09/09/1998 (BGBI. I S.2726).

23. Gesetz zur Modernisierung des Investmentwesens und zur Besteuerung von Investmentvermögen (Investmentmodernisierungsgesetz), BGBl. I 2003 S. 2676.

24. Gesetz zur Änderung des Investmentgesetzes und zur Anpassung anderer Vorschriften (Investmentänderungsgesetz), BGBl. I 2007 S. 3089.

25. Grundmann, S.: European Company Law, Organisation, Finance and Capital Markets, Antwerpen-Oxford, 2007.

26. Gruhn, A. M.: Die deutsche Investmentaktiengesellschaft - Ein Investmentfondsprodukt im Mantel einer Aktiengesellschaft, Berlin, 2011.

27. Guide de l'investisseur, Instruments financiers, [https://www.ing.lu/webing/ content/dam/ing/PDF/personal/invest/investor-guide/guide_de_1_investisseur_ fr.pdf], accessed on 03/09/2020.

28. HANFA, [https://www.hanfa.hr/], accessed on 9/11/2020.

29. Hermanns, M.: Die Investmentaktiengesellschaft nach dem Investmentmodernisierungsgesetz - eine neue Gesellschaftsform, Zeitschrift für Wirtschaftsrecht, 2004.

30. Investment Funds Act, Official Gazzette Nos. 107/95, 12/96, 114/01.

31. Johnson, L. P. Q., Protecting mutual fund investors: an inevitable eclecticism, in: Birdthistle, W. A., Morley, J. (eds), Research Handbook on the Regulation of Mutual Funds, Cheltenham, 2018.

32. Kapitalanlagegesetzbuch vom 4. Juli 2013 (BGB1. I S. 1981), das zuletzt durch Artikel 5 des Gesetzes vom 19. März 2020 (BGBl. I S. 529) geändert worden ist.

33. Kaplan, S. N., Stromberg, P.: Leveraged Buyouts and Private Equity, in: Bratton, W.W., McCahery, J.A. (ur.) Institutional Investor Activism, Hedge Funds and Private Equity, Economics and Regulation, Oxford, 2015.

34. Köndgen, J., Schmies, C.: § 113. Investmentgeschäft, in Schimansky, H., Bunte, H-J., Lwowski, H-J. (eds): Bankrechts-Handbuch, München, 2017.

35. Kirk, E.: Open-ended versus closed-ended funds - what's the difference?, Equity, 33 (10) 2019.

36. Kremer, C., Lebbe, I.: Organismes De Placement Collectif et Véhicules d'investissement apparentés en droit luxembourgeois, Larcier, 2007.

37. Krig, A. K.: Toward better mutual fund governance, in Birdthistle, W. A., Morley, J. (eds): Research Handbook on the Regulation of Mutual Funds, Cheltenham, 2018.

38. Lavoie, G.: Should Private Venture fund Managers import the mutual funds and hedge fund open-ended structure?, Montreal, 2015, [https://www.lavery. ca/upload/pdf/lavoieguillaume/EMBA-FinalPaper-FINAL.PDF], accessed on 13/6/2020.

39. Law on Investment Funds, Official Gazzette No. 150/05. 
40. Law on Privatization Investment Funds, Official Gazzette Nos. 109/97, 114/01.

41. Loi du 10 août 1915 concernant les sociétés commerciales.

42. Loi du 25 août 1983 relative aux organismes de placement collectif.

43. Loi du 30 mars 1988 relative aux organismes de placement collectif.

44. Loi du 20 décembre 2002 concernant les organismes de placement collectif et modifiant la loi modifiée du 12 février 1979 concernant la taxe sur la valeur ajoutée.

45. Morley, J.: The Separation of Funds and Managers: A Theory of Investment Fund Structure and Regulation, The Yale Law Journal, 123 (5) 2014, [https://digitalcommons.law.yale.edu/cgi/viewcontent.cgi?article=5621\&context=ylj], accessed on $05 / 05 / 2020$.

46. Open-ended Investment Funds with Public Offering Act, Official Gazzette, Nos. $16 / 2013,143 / 2014$.

47. Open-ended Investment Funds with Public Offering Act, Official Gazzette Nos. 44/2016, 126/2019.

48. Raab, W.: Kapitalverwaltungsgesellschaft (KVG), in: Raab, W., Grundlagen des Investmentfondsgeschäftes, Frankfurt am Main, 2019.

-DOI: https://doi.org/10.1007/978-3-658-24155-1

49. Rounds, C. E., Dehio, A.: Publicly-Traded Open End Mutual Funds in Common Law and Civil Jurisdictions: A Comparison of Legal Structures, New York University Journal of Law \& Business, 3 (2) 2007.

50. Sachtleber, O. W.: Zivilrechtliche Strukturen von open-end-Investmentfonds in Deutschland und England, Göttingen, 2011.

51. Spangler, T.: The Law of Private Investment Funds, Third Edition, Oxford, 2018.

52. Steck, K-U., Fisher, C.: Better than SICAV, International Financial Law Review, 29 (1) 2010.

53. Thoma, G. G., Steck, K-U., The German Investmentaktiengesellschaft (closedend fund): Investment Alternative or Legislative Failure?, University of Pennsylvania Journal of International Economic Law, 23 (1) 2002.

54. Zetzsche, D. A., Preiner, C. D.: Scope of the AIFMD, in Zetzsche, D. A. (ed.): The Alternative Investment Fund Managers Directive, Alphen aan den Rijn, 2015.

55. Zetzsche, D. A.: The anatomy of European investment fund law, in: Birdthistle, W.A., Morley, J. (eds): Research Handbook on the Regulation of Mutual Funds, Cheltenham, 2018.

56. Wegman, H.: Investor protection: towards additional EU regulation of investment funds?, Leiden, 2016. 